\title{
Determination of Concentration of Heavy Metals in Fruits, Vegetables, Groundwater, and Soil Samples of the Cement Industry and Nearby Communities and Assessment of Associated Health Risks
}

\author{
Ghazala Yaqub ${ }^{D},{ }^{1}$ Arooj Khan, ${ }^{1}$ Muhammad Zishan Ahmad, ${ }^{2}$ and Umadia Irshad \\ ${ }^{1}$ Department of Environmental Sciences, Kinnaird College for Women, Lahore, Pakistan \\ ${ }^{2}$ Department of Veterinary Pathology, Faculty of Veterinary and Animal Sciences, \\ PMAS Arid Agriculture University Rawalpindi, Rawalpindi, Pakistan
}

Correspondence should be addressed to Ghazala Yaqub; ghazala_yaqub@yahoo.com

Received 26 July 2021; Revised 26 August 2021; Accepted 17 September 2021; Published 30 September 2021

Academic Editor: Muhammad Faisal Manzoor

Copyright $(2021$ Ghazala Yaqub et al. This is an open access article distributed under the Creative Commons Attribution License, which permits unrestricted use, distribution, and reproduction in any medium, provided the original work is properly cited.

This study was conducted to estimate the heavy metal pollution in groundwater, soil, fruits, and vegetables within the cement industry and its vicinity. Seven different fruits and vegetables and seven heavy metals (Cd, $\mathrm{Zn}, \mathrm{Ni}, \mathrm{Co}, \mathrm{Cu}, \mathrm{Cr}$, and $\mathrm{Mn}$ ) were selected for analysis in soil, groundwater, fruit, and vegetable samples by atomic absorption spectrometry (AAS). Results of this study were compared with the National and International Standards of Pak NSWQD, WHO, and USEPA. The pH of soil and groundwater samples was within limits (WHO and Pak NSDWQ standards are 6.5-8.5). The concentration of $\mathrm{Cr}$ and $\mathrm{Cu}$ in groundwater samples was above the WHO and Pak NSDWQ standards $(\mathrm{Cr}=0.05 \mathrm{ppm} ; \mathrm{Cu}=2 \mathrm{ppm})$. Vegetable samples were contaminated with metals except for $\mathrm{Ni}$ and $\mathrm{Mn}$, whereas, in fruit samples, Mn and Cd were not present (WHO limit for $\mathrm{Mn}=5 \mathrm{ppm})$. The mean concentration of $\mathrm{Ni}$ was high in fruits $(\mathrm{WHO}$ limit $=10 \mathrm{ppm})$, Zn was high in vegetables $(\mathrm{WHO}$ limit $=100 \mathrm{ppm})$, and $\mathrm{Cu}$ was high in soil and groundwater $(\mathrm{WHO}$ limit for soil $=36 \mathrm{ppm}$; for groundwater $=2 \mathrm{ppm})$. The results of daily intake of metals (DIM) for fruits, vegetables, and groundwater were compared with TDI by USEPA and PTDI of the $\mathrm{WHO} / \mathrm{FAO}$, and all were within the recommended limits. Calculated BAF for the selected environmental sample, that is, Indian Squash, lime fruit, and so on, was in order of $\mathrm{Co}>\mathrm{Cr}>\mathrm{Cu}$ and THQ; HRI was calculated to estimate the human health risk, and they were in a trend of $\mathrm{Ni}>\mathrm{Co}>\mathrm{Cd}>\mathrm{Cr}$ and for $\mathrm{HRI} \mathrm{Co}>\mathrm{Cr}$.

\section{Introduction}

In the industrialized world, construction material is the most important nonfuel material that flows worldwide, that is, cement. Portland cement is used extensively in concrete formation and as a binding agent in mortars [1]. Worldwide cement production is increasing from 1990 to 2050, and it is the second most demanded product in the world after water. The cement industry is one of the most important industries in Pakistan and it plays a significant role in the economic development of Pakistan. Pakistan's cement industry is fulfilling the domestic demand of the country and exporting it to foreign countries as well. At present, twenty cement firms are operational and producing cement at their maximum capacity in Pakistan. Most of the cement industries are located in the southern and northern regions as they are rich in clay, limestone, and other raw materials required for the production of cement [2].

The demand for cement will increase, especially in developing countries like Pakistan and India where the demand for infrastructure and housing societies is high [3]. In 2012, the global production rate of cement reached 3.6 billion tons. It is expected to grow in the coming years by $0.8-1.2 \%$ per year and the projected production rate will be between $3700 \mathrm{Mt}$ (megatons) and 4,400 Mt. The demand for cement and concrete is increasing. Due to the limited 
resources, including fossil fuels and raw materials, the cement industries have to face many difficulties. With rapid industrialization, the anxiety related to the environment is also on the increase [4].

The production of cement is an energy-intensive process, and it requires a large amount of nonrenewable fuel and organic raw material. It was estimated that cement industrial activities contribute $5 \%$ to $6 \%$ of the total percentage of greenhouse gas emissions from human activities, to the environment. Trace elements and toxic metals are released into air when industrial waste and secondary fuel sources are burnt in cement kilns as an alternative fuel source. Gases released from the cement industry usually contain fluorides, oxides, $\mathrm{NO}_{\mathrm{X}}, \mathrm{SO}_{\mathrm{X}}, \mathrm{CO}_{2}$, and heavy metals [5].

Cement dust can travel long distances through air and rain, and it has the ability to bioaccumulate in plants and soil. Heavy metals and other trace elements present in cement dust can enter the food chain through biomagnification and cause several health hazards to the living beings. Due to the properties of heavy metals like high bioaccumulative potential, persistence, and toxicity, heavy metal pollution is a major environmental concern [6]. Trace amounts of some metals are required for the growth and functioning of living organisms, but if consumed in higher quantities, they can be toxic for humans and aquatic life [7]. A high concentration of toxic metals in groundwater enters the food chain and causes substantial risk [8]. Exposure to heavy metals causes severe human health implications such as infertility, neurotoxicity, and cardiovascular and skeletal diseases in human beings [9]. Moreover, a genotoxic carcinogen is a group of toxicants that causes liver and kidney disorders in humans due to exposure to heavy metals $[10,11]$.

Crushing, bagging, and transportation of limestone increase the risk of chemical spread over a large area. It triggers a variety of problems, especially for soil and vegetation, because of its alkaline nature. Cement production plants are now considered a major source of metal pollution in the environment. They emit organic and inorganic chemicals in the form of metals and metalloids like $\mathrm{Cu}, \mathrm{Ni}, \mathrm{Zn}, \mathrm{Cr}, \mathrm{Fe}, \mathrm{Cd}$, $\mathrm{As}$, and $\mathrm{Pb}$. Some of them are toxic to human and plant life even at very low concentrations [12]. Thus this research was designed in order to determine and quantify heavy metals in the groundwater samples, soil sediments, fruits, and vegetables by atomic absorption spectrometry and this study will be significant in the determination of estimated health risk especially carcinogenic risk by determining the Health Risk Index (HRI) and Target Hazard Quotient.

\section{Methodology}

2.1. Sample Collection. Samples of fruits, vegetables, groundwater, and soil were collected from the cement industry and nearby areas. Drinking water samples were stored in autoclaved bottles to avoid any contamination, whereas the samples of soil were collected and stored in sealed plastic bags for further analysis. Total seven numbers of fresh fruits (i.e., melon (Cucumis melo), pear (Pyrus), grapefruit (Citrus $\times$ paradisi), mosambi (Citrus limetta), lime fruit
(Citrus $\times$ aurantiifolia), guava (Psidium guajava), and apple (Malus domestica)) and vegetables (i.e., eggplant (Solanum melongena), turnip (Brassica rapa subsp. rapa), bottle gourd (Lagenaria siceraria), green chilies (Capsicum annuum), cauliflower (Brassica oleracea var. botrytis), Indian squash (Praecitrullus fistulosus), and sapsicum (Capsicum annuum group) were collected. The location of the cement industry is shown in Figure 1.

2.2. Sample Preparation of Fruits and Vegetables. Samples of fruits (i.e., apple, melon, pear, grapefruit, mosambi, lime fruit, and guava) and vegetables (i.e., eggplant, bottle gourd, green chilies, cauliflower, Indian squash, capsicum, and turnip) were washed thoroughly to remove the dust particles and other pollutants from the outer surface. Then, they were sliced down into small pieces $(0.5 \mathrm{~cm})$ and sun-dried for about 10 days. After getting completely dried, they were grounded into powder form and stored in plastic sealed bags with proper labels [13].

2.3. Digestion of Metals. For digestion of metals, $30 \%$ of hydrogen peroxide $\left(\mathrm{H}_{2} \mathrm{O}_{2}\right)$ and $50 \%$ of nitric acid solution were prepared. $\mathrm{H}_{2} \mathrm{O}_{2}$ solution was labeled as solution $\mathrm{A}$ and the nitric acid solution was labeled as solution $\mathrm{B}$ [14].

2.4. Soil Samples. For the preparation of soil samples, $5 \mathrm{ml}$ of solution A and $5 \mathrm{ml}$ of solution $B$ were added to a 1 gram of soil sample with $10 \mathrm{ml}$ of deionized water. After this, the solution was transferred to a round bottom flask. This round bottom flask was placed in a large beaker more than halffilled with silica gel, a piece of Styrofoam was fitted around the neck of the flask to provide support, and a small piece of Styrofoam was placed within the neck of the round bottom flask to avoid any outflow of solution during digestion. After setting the flask in a beaker, it was placed for about 40 seconds in a microwave for digestion with intervals of 10 seconds. Within these intervals, the flask was taken out from the beaker to let it cool down and then again placed in the microwave for further digestion. After complete digestion of metal, the solution was diluted with $100 \mathrm{ml}$ of distilled water and stored in a vial for analysis by atomic absorption spectrometry [13].

2.5. Fruits and Vegetables and Groundwater Samples. The same procedure was followed for fruits and vegetables. In groundwater samples collected from the factory and community area, no digestion was required. Water samples were filtered and stored in vials and labeled.

2.6. Human Risk Assessment. Human risk assessment was done by calculating different indexes like THQ, DIM, HRI, and BAF [15]. The daily intake of metals (DIM) was calculated by using the following formula:

$$
\mathrm{DIM}=\frac{C C_{\text {metal }} \times C C_{\text {factor }} \times D D_{\text {intake }}}{B_{\text {weight }}},
$$




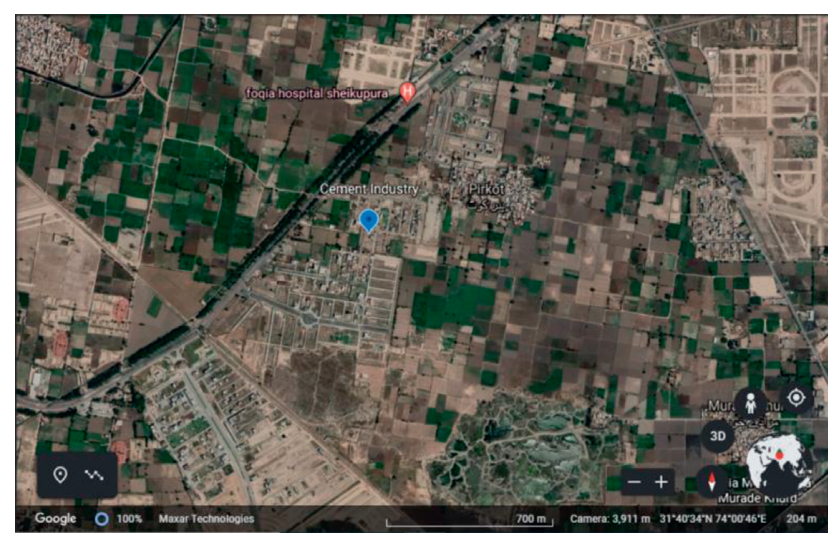

Figure 1: Map of study area (source: Google Earth).

where $C_{\text {metal }}=$ concentration of metal in food, $C_{\text {factor }}=$ conversion factor $0.085, D_{\text {intake }}=$ average daily intake of food $(0.585 \mathrm{~kg} /$ person/day of vegetables, $0.256 \mathrm{~kg} /$ person/day, and 1.5 liters/person/day of water intake of the selected area), $B_{\text {weight }}=$ average body weight for the adult population, $\mathrm{BAF}=C_{\text {plants }} / C_{\text {soil }}, \quad C_{\text {plants }}=$ concentration of metal in plant, and $C_{\text {soil }}=$ concentration of metal in soil.

Health risk index $(\mathrm{HRI})=\mathrm{DIM} / \mathrm{ADI}$, where DIM $=$ daily intake of metal and ADI = acceptable daily intake.

Target hazard quotient (THQ) is as follows:

$$
\mathrm{THQ}=\left[\frac{\left(\mathrm{EFr} \times \mathrm{ED}_{\text {tot }} \times \mathrm{IFR} \times \mathrm{C}\right)}{(\mathrm{RfDo} \times \mathrm{BWa} \times \mathrm{ATn})}\right] \times 10^{-3},
$$

where $\mathrm{EFr}=$ the exposure frequency $(365$ days/year $)(122$ days/year), $\mathrm{ED}_{\text {tot }}=$ exposure duration (66-year average life span), IFR $=$ food ingestion rate, $\mathrm{C}=$ concentration $(\mathrm{ppm})$, $\mathrm{RfDo}=$ oral reference dose $\left(\mu \mathrm{g} \mathrm{g}^{-1} \mathrm{day}^{-1}\right), \mathrm{BWa}=$ adult body weight $(60 \mathrm{~kg})$, and $\mathrm{ATn}=$ average time for noncarcinogens (it is calculated by $\mathrm{EFr} \times \mathrm{ED}_{\text {tot }}$ ).

\section{Results and Discussion}

The groundwater samples of the cement industry and the nearby community were odorless, and the taste was acceptable. In physical appearance, all the samples were colorless as within the physical appearance standards for drinking water of Pakistan NSDWQ and WHO drinking water quality guidelines. The groundwater $\mathrm{pH}$ values are shown in Figure 2. These are found in the range between 6.5 and 8.5. The $\mathrm{pH}$ of cement industry water samples was 6.58 to 7.82 , and the $\mathrm{pH}$ values for community water samples rages from 7.63 to 7.96 . All $\mathrm{pH}$ values were within limits given by $\mathrm{WHO}$ and Pakistan standard values NSQWQ.

The $\mathrm{pH}$ of soil samples collected from the cement industry ranges between 6.68 and 7.81 and the soil samples collected from the nearby area of industry range from 7.06 to 7.53 which was neutral slightly towards alkaline.

Heavy metals were detected in the collected samples through atomic absorption spectrometry (AAS) in different concentrations given in Table 1. Cobalt was present in both soils (cement industry and in the nearby community). The concentration of cobalt varies from $1.1 \mathrm{ppm}$ to $1.89 \mathrm{ppm}$. The

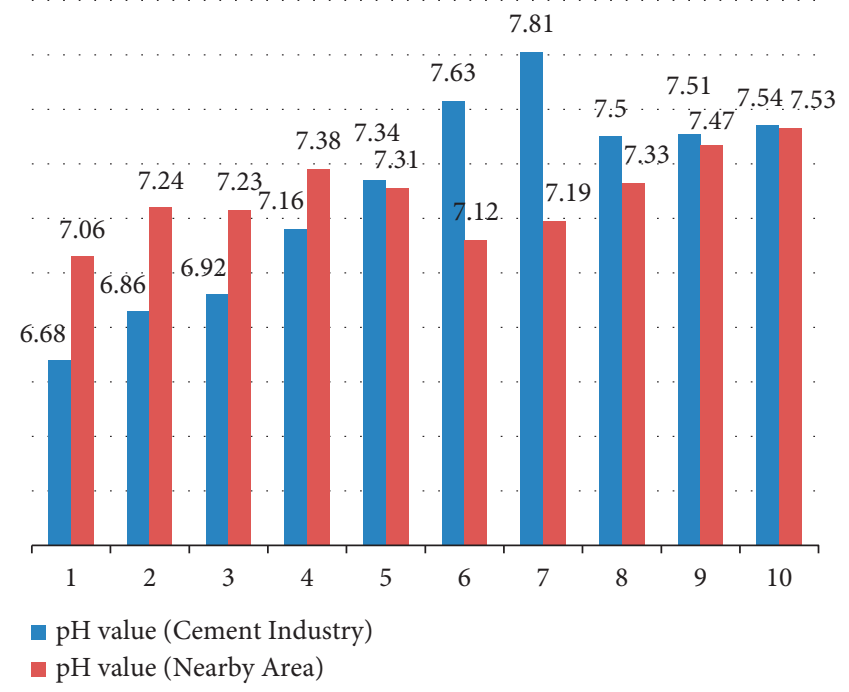

FIgURE 2: $\mathrm{pH}$ results of soil samples collected from the cement industry and its nearby area.

concentration of chromium in community area soil was from $0.8 \mathrm{ppm}$ to $1.35 \mathrm{ppm}$, and the same goes for the chromium levels in cement industry soil. Although chromium was detected in the study area, its concentration levels do not exceed any of the soil standards given by WHO. The concentration of copper in soil samples was also within the limits of WHO (36 ppm).

Heavy metals such as $\mathrm{Ni}, \mathrm{Cd}, \mathrm{Cr}, \mathrm{Co}, \mathrm{Mn}, \mathrm{Cu}$, and $\mathrm{Zn}$ were detected in the groundwater samples $[16,17]$. The results of heavy metal detection showed that $\mathrm{Ni}$ was below the detection limit in the groundwater [18]. The concentration of chromium in groundwater was between $0.8 \mathrm{ppm}$ and $5 \mathrm{ppm}$ exceeding the standard values of WHO, Pak NSDWQ, that is, $0.05 \mathrm{ppm}$, and also crossing the standard limit of USEPA. The highest concentration of chromium was observed in samples numbers 3,5 , and 8 of the cement industry, whereas in community groundwater samples, the highest concentration of $\mathrm{Cr}$ was $5 \mathrm{ppm}$ in sample 3 while $\mathrm{Zn}$, $\mathrm{Cd}$, and $\mathrm{Mn}$ were not present. High $\mathrm{Cr}$ intake by the human body can cause damage to the intestinal tract [19]. The mobility of chromium in soil depends on several soil factors like clay content, soil characteristics, and organic content. With the increase of soil $\mathrm{pH}$, chromium leaches down deeper in water reservoirs and contaminated groundwater sources. Most of the chromium which leaches down from soil to groundwater is an insoluble and unabsorbed form [20].

Copper enters surface and groundwater sources by contaminated soil and polluted urban dust. Several studies reported that urban areas are highly contaminated with $\mathrm{Cr}, \mathrm{Ag}$, $\mathrm{Cu}, \mathrm{Mn}, \mathrm{Pb}$, and $\mathrm{Zn}$ [21]. Most critical levels of copper were reported in all groundwater samples. Detected values of copper were $1.75 \mathrm{ppm}, 2 \mathrm{ppm}, 2.5 \mathrm{ppm}, 3.2 \mathrm{ppm}$, and $3.6 \mathrm{ppm}$, whereas, in the community, the concentration ranges from $1.5 \mathrm{ppm}$ to $36 \mathrm{ppm}$. All samples exceeded the standard limits as the maximum allowable limit for copper in drinking water by WHO, PAK NSDWQ, is $2 \mathrm{ppm}$, and by USEPA, it is $1.3 \mathrm{ppm}$. Heavy metals like copper leached down from soil to groundwater and contaminate the drinking water resources 
TABLE 1: Results of heavy metal concentration in samples.

\begin{tabular}{|c|c|c|c|c|c|c|c|}
\hline Sample & $\begin{array}{l}\text { Cobalt } \\
(\mathrm{ppm})\end{array}$ & $\begin{array}{l}\text { Nickel } \\
(\mathrm{ppm})\end{array}$ & $\begin{array}{l}\text { Cadmium } \\
(\mathrm{ppm})\end{array}$ & $\begin{array}{l}\text { Chromium } \\
(\mathrm{ppm})\end{array}$ & $\begin{array}{l}\text { Zinc } \\
(\mathrm{ppm})\end{array}$ & $\begin{array}{c}\text { Copper } \\
(\mathrm{ppm})\end{array}$ & Manganese (ppm) \\
\hline \multicolumn{8}{|l|}{ Vegetables } \\
\hline Eggplant (Solanum melongena) & 1.85 & - & 0.6 & 0.8 & 9.98 & 1.5 & - \\
\hline Turnip (Brassica rapa subsp. rapa) & & - & - & 0.8 & - & - & - \\
\hline Bottle gourd (Lagenaria siceraria) & 1.97 & - & - & - & 10.2 & 1.5 & - \\
\hline Green chilies (Capsicum annuum) & 4 & - & - & - & 4.18 & - & - \\
\hline $\begin{array}{l}\text { Cauliflower (Brassica oleracea var. } \\
\text { botrytis) }\end{array}$ & 4 & - & - & 0.8 & 4.47 & - & - \\
\hline $\begin{array}{l}\text { Indian squash (Praecitrullus } \\
\text { fistulosus) }\end{array}$ & 4.1 & - & - & 0.8 & 6.8 & 1.5 & - \\
\hline $\begin{array}{l}\text { Capsicum (Capsicum annuum } \\
\text { group) }\end{array}$ & & - & - & 0.8 & - & - & - \\
\hline WHO & 0.01 & 67 & 0.1 & 1.3 & 100 & 73 & 6.61 \\
\hline USEPA & - & - & - & - & - & 1.3 & - \\
\hline \multicolumn{8}{|l|}{ Fruits } \\
\hline Melon (Cucumis melo) & 3.9 & - & - & - & 4.2 & - & - \\
\hline Pear (Pyrus) & 1.42 & - & - & - & - & - & - \\
\hline Grapefruit (Citrus $\times$ paradisi) & 1.42 & - & - & 0.8 & 3.9 & - & - \\
\hline Mosambi (Citrus limetta) & 0.7 & - & - & 0.8 & 1.25 & - & - \\
\hline Lime fruit (Citrus $\times$ aurantiifolia) & 1 & - & - & 0.8 & 1.2 & - & - \\
\hline Guava (Psidium guajava) & 1.75 & 4.6 & - & 1.35 & 0.9 & - & - \\
\hline Apple (Malus domestica) & - & - & - & - & - & 1.5 & - \\
\hline WHO & - & 10 & 0.02 & 1.3 & 60 & 10 & 5 \\
\hline \multicolumn{8}{|l|}{ Soil samples from the community } \\
\hline $0-1$ & 1.1 & - & - & - & - & 2.5 & - \\
\hline $0-2$ & 1.1 & - & - & - & - & 2 & 1.68 \\
\hline $0-3$ & 1.75 & - & - & - & - & 1.5 & 1.9 \\
\hline $0-4$ & 1.86 & - & - & 0.8 & - & 1.5 & 1.1 \\
\hline $0-5$ & 1.87 & - & - & 0.8 & - & - & 2.03 \\
\hline $0-6$ & 1.88 & - & - & 1.35 & - & - & - \\
\hline $0-7$ & 1.87 & - & - & & - & 2 & - \\
\hline $0-8$ & 1.86 & - & - & - & - & 2 & 0.85 \\
\hline $0-9$ & 1.88 & - & - & 0.8 & - & - & 2.1 \\
\hline $0-10$ & 1.89 & - & - & - & - & 1.75 & 1.7 \\
\hline \multicolumn{8}{|l|}{ Soil samples from the industry } \\
\hline $\mathrm{F}-1$ & 1.86 & - & - & 0.8 & - & 1.5 & - \\
\hline $\mathrm{F}-2$ & 1.75 & - & - & - & - & 2 & - \\
\hline $\mathrm{F}-3$ & 1.87 & - & - & - & - & 1.75 & - \\
\hline $\mathrm{F}-4$ & 1.85 & - & - & - & - & 3 & - \\
\hline $\mathrm{F}-5$ & 1.86 & - & - & 1.35 & - & 1.75 & - \\
\hline $\mathrm{F}-6$ & 1.85 & - & - & 0.8 & - & 3.2 & - \\
\hline $\mathrm{F}-7$ & 1.87 & - & - & 0.8 & - & 1.75 & - \\
\hline $\mathrm{F}-8$ & 1.87 & - & - & 0.8 & - & 1.5 & - \\
\hline $\mathrm{F}-9$ & 1.86 & - & - & 0.8 & - & 2 & - \\
\hline $\mathrm{F}-10$ & 1.85 & - & - & 0.8 & - & 2.5 & - \\
\hline WHO & 20 & 35 & 0.8 & 100 & 50 & 36 & 12 \\
\hline \multicolumn{8}{|c|}{ Groundwater samples from the industry } \\
\hline $\mathrm{w} / \mathrm{f}-1$ & 1.86 & - & - & 0.3 & - & 2.5 & - \\
\hline 2 & 1.75 & - & - & 0.8 & - & 1.75 & - \\
\hline 3 & 1.42 & - & - & 1.35 & - & 2 & - \\
\hline 4 & 1.75 & - & - & 0.8 & - & 2.5 & - \\
\hline 5 & 1.85 & - & - & 1.35 & - & 3.6 & - \\
\hline 6 & 1.86 & - & - & 0.8 & - & 2 & - \\
\hline 7 & 1.85 & - & - & 0.8 & - & 3.2 & - \\
\hline 8 & 1.75 & - & - & 1.35 & - & 2 & - \\
\hline
\end{tabular}


TABLE 1: Continued.

\begin{tabular}{|c|c|c|c|c|c|c|c|}
\hline Sample & $\begin{array}{l}\text { Cobalt } \\
(\mathrm{ppm})\end{array}$ & $\begin{array}{l}\text { Nickel } \\
(\mathrm{ppm})\end{array}$ & $\begin{array}{l}\text { Cadmium } \\
\text { (ppm) }\end{array}$ & $\begin{array}{c}\text { Chromium } \\
\text { (ppm) }\end{array}$ & $\begin{array}{c}\text { Zinc } \\
(\mathrm{ppm})\end{array}$ & $\begin{array}{c}\text { Copper } \\
(\mathrm{ppm})\end{array}$ & Manganese (ppm) \\
\hline \multicolumn{8}{|c|}{ Groundwater samples from the community } \\
\hline $\mathrm{w} / 0-1$ & - & - & - & 0.3 & - & 2 & - \\
\hline 2 & - & - & - & 1.35 & - & 3.2 & - \\
\hline 3 & - & - & - & 5 & - & 3.2 & - \\
\hline 4 & - & - & - & - & - & 2 & - \\
\hline 5 & - & - & - & - & - & 2.5 & - \\
\hline 6 & - & - & - & - & - & 3.2 & - \\
\hline 7 & - & - & - & - & - & 3.6 & - \\
\hline 8 & - & - & - & - & - & 1.5 & - \\
\hline WHO & - & 0.02 & 0.003 & 0.05 & 3 & 2 & 0.5 \\
\hline NSDWQ & - & 0.02 & 0.01 & 0.05 & 5.0 & 2 & 0.5 \\
\hline
\end{tabular}

[19]. Copper is essential for the human body in trace amounts, high levels of copper can result in renal failure, liver damage, anemia, and intestinal and stomach problems. Most common sources of copper in drinking water are copper pipes and additives which are added in water tanks and pipes to control algal growth [22]. All heavy metals were detected in fruits and vegetables except for manganese [23].

Cd concentration $(0.6 \mathrm{ppm})$ in eggplant was found higher than the CODEX, EU, and WHO standards for cadmium concentration in food. Cadmium is easily taken up by the plants and food crops grown near or within the vicinity of the cement industry. Different studies have witnessed a high concentration of cadmium in food crops near the cement industries. Plants have the capacity to accumulate $\mathrm{Cd}$ from soil and cause serious threats to consumers [24, 25]. Vegetables grown in the industrial area of Faisalabad also showed a very high concentration of Cd [22].

Zinc is quite immobile in the soil; however, the majority of the food crops have a high level of accumulated zinc. High concentrations of zinc have been reported in vegetables and fruits grown within the cement industry area and near to it $[12,24]$. Zinc was present in almost all of the vegetables as follows: eggplant $9.98 \mathrm{ppm}$, bottle gourd $10.2 \mathrm{ppm}$, green chilies 4.18, cauliflower $4.47 \mathrm{ppm}$, and Indian squash $6.8 \mathrm{ppm}$, except for the turnip and capsicum. The levels of $\mathrm{Zn}$ in all of the vegetables were within the recommended standards of WHO which was $100 \mathrm{ppm}$. The presence of zinc in soil interrupts the breakdown of organic matter by microbes and plants usually accumulate an excessive amount of $\mathrm{Zn}$, which their system cannot handle at all. The production rate of zinc in this modern age is increasing with time, which means that it will end up in the ecosystem and enters the food chain [22]. Copper was also present in eggplant, bottle gourd, Indian squash, and apple. In the presented study, copper was also reported in groundwater samples, and soil are given in Table 2. Most of the copper leached down from soil to groundwater sources, due to which the amount of $\mathrm{Cu}$ present in soil and plants is less as compared to groundwater. Copper levels were usually high in industrial area vegetation and groundwater as it can travel through air over large distances. From the soil, it leached down in water reservoirs [12, 19].

The majority of heavy metals were detected in the soil samples of the cement industry and the nearby area. Co, $\mathrm{Mn}, \mathrm{Cr}$, and $\mathrm{Cu}$ were detected at different concentrations in soil. The level of cobalt in soil ranges from $1.1 \mathrm{ppm}$ to $1.89 \mathrm{ppm}$. Cobalt was reported in the soil and in a number of vegetables and fruits.
In vegetable samples, the concentration levels of cobalt were as follows: Indian squash $>$ cauliflower $>$ green chilies $>$ bottle gourd > eggplant with concentrations of $4.1 \mathrm{ppm}, 4 \mathrm{ppm}$, $1.97 \mathrm{ppm}$, and $1.85 \mathrm{ppm}$. In case of fruits, Co was present in all of them except for apple, and the levels of Co range from $0.7 \mathrm{ppm}$ to $3.9 \mathrm{ppm}$ in the order of melon $>$ guava $>$ pear $>$ grapefruit $>$ lime fruit $>$ mosambi. AAS detected $\mathrm{Cr}$ not only in groundwater and vegetables but also in the fruits and soil of the study area. The concentration of $\mathrm{Cr}$ was reported by several researchers. The highest concentration of $\mathrm{Cr}$ was found in sample 6 of the community and sample 5 of cement industry soil which was $1.35 \mathrm{ppm}$. Overall, the Cr contamination in soil was within the WHO standards. Contaminated soil with heavy metals increases the risk of metal uptake by plants and accumulation in different edible parts $[24,25]$. Plants grown near the surface of contaminated soil have a high potential to uptake heavy metals as the contaminants were absorbed by the plants and stick on the outer surface of plants $[16,26,27]$. Manganese was only detected in the community's soil, the highest concentration of Mn was $2.03 \mathrm{ppm}$ in sample 5, and $1.1 \mathrm{ppm}$ was the lowest concentration in sample 4. No manganese was detected in the soil samples of the cement industry. Vegetation grown in Mn soil can decrease the level of $\mathrm{Ca}$ and $\mathrm{Mg}$ in plants, disturb the protein synthesis, and increase the risk of nitrate uptake from the soil [16]. Nitrogen is added to the soil in the form of fertilizers and contaminates the soil from various natural and anthropogenic sources.

The soil standard for copper by WHO is $36 \mathrm{ppm}$; when compared with the concentration levels of $\mathrm{Cu}$ in the soil, the concentration of copper for all the samples falls within the recommended range of standards. In fruit samples, $\mathrm{Ni}$ and $\mathrm{Cu}$ were detected in apples as the concentration of $\mathrm{Cu}$ was $1.5 \mathrm{ppm}$ falling within the standards of CODEX and WHO of $40 \mathrm{ppm}$ and $10 \mathrm{ppm}$, whereas the concentration level of $\mathrm{Ni}$ was $4.6 \mathrm{ppm}$; it was also within the recommended standard of WHO. Plants uptake metals from the soil, whereas some of the metals leach down from soil to groundwater.

Mean concentrations of all heavy metals were calculated to determine the highest concentration of metals in soil, groundwater, fruits, and vegetables (Table 2).

3.1. Mean Concentration Trend of Heavy Metals in Vegetables. The trend of the study area was $\mathrm{Zn}(7.126)>\mathrm{Co}(3.184)>\mathrm{Cu}$ $(1.5)>\mathrm{Cr}(0.8)>\mathrm{Cd}(0.6)$, and in fruits, it was $\mathrm{Ni}(4.6)>\mathrm{Zn}$ $(2.29)>\operatorname{Co}(1.698)>\mathrm{Cu}(1.5)>\mathrm{Cr}(0.9375)$. 
TABLE 2: Mean concentration of heavy metals (ppm).

\begin{tabular}{|c|c|c|c|c|c|c|c|}
\hline Samples & Co & $\mathrm{Zn}$ & $\mathrm{Ni}$ & $\mathrm{Cu}$ & $\mathrm{Mn}$ & $\mathrm{Cd}$ & $\mathrm{Cr}$ \\
\hline Vegetables & 3.184 & 7.126 & - & 1.5 & - & 0.6 & 0.8 \\
\hline Fruit & 1.698 & 2.29 & 4.6 & 1.5 & - & - & 0.9375 \\
\hline Soil from the community & 1.706 & - & - & 1.8928 & 1.6228 & - & 0.9375 \\
\hline Soil from the cement industry & 1.849 & - & - & 2.095 & - & - & 0.8785 \\
\hline Groundwater sample from the cement industry & 1.9387 & - & - & 2.4437 & - & - & 0.94275 \\
\hline Groundwater sample from the community & - & - & - & 2.65 & - & - & 2.216 \\
\hline
\end{tabular}

TABLE 3: Comparison of daily intake of metal with tolerable daily intake (mg/kg/day) and provisional tolerable daily intake ( $\mathrm{mg} / \mathrm{kg} / \mathrm{day})$ for vegetables, fruits, and groundwater samples.

\begin{tabular}{|c|c|c|c|c|c|c|c|}
\hline Sample & $\mathrm{Cr}$ & $\mathrm{Ni}$ & $\mathrm{Cd}$ & $\mathrm{Zn}$ & $\mathrm{Cu}$ & $\mathrm{Mn}$ & Co \\
\hline \multicolumn{8}{|l|}{ Vegetables } \\
\hline Eggplant (Solanum melongena) & 0.000663 & - & 0.00022525 & 0.008270925 & 0.001243125 & - & - \\
\hline Bottle gourd (Lagenaria siceraria) & - & - & - & 0.00845325 & 0.001243125 & - & - \\
\hline Green chilies (Capsicum annuum) & - & - & - & 0.003464175 & - & - & - \\
\hline $\begin{array}{l}\text { Cauliflower (Brassica oleracea var. } \\
\text { botrytis) }\end{array}$ & 0.000663 & - & - & 0.0037045125 & - & - & - \\
\hline Indian squash (Praecitrullus fistulosus) & 0.000663 & - & - & 0.0056355 & 0.001243125 & - & - \\
\hline Capsicum (Capsicum annuum group) & 0.000663 & - & - & - & - & - & - \\
\hline Turnip (Brassica rapa subsp. rapa) & 0.000663 & - & - & - & - & - & - \\
\hline \multicolumn{8}{|l|}{ Fruits } \\
\hline Apple (Malus domestica) & - & 0.00172691666 & - & - & 0.000563125 & - & - \\
\hline Melon (Cucumis melo) & - & - & - & 0.00157675 & - & - & - \\
\hline Pear (Pyrus) & - & - & - & & - & - & - \\
\hline Grapefruit (Citrus $\times$ paradisi) & 0.00030033333 & - & - & 0.001464125 & - & - & - \\
\hline Mosambi (Citrus limetta) & 0.00030033333 & - & - & 0.00046927083 & - & - & - \\
\hline Lime fruit (Citrus $\times$ aurantiifolia) & 0.00030033333 & - & - & 0.0004505 & - & - & - \\
\hline Guava (Psidium guajava) & 0.0005068125 & - & - & 0.000337875 & - & - & - \\
\hline \multicolumn{8}{|l|}{ Groundwater } \\
\hline 1 & 0.0006375 & - & - & - & 0.0053125 & - & 0.0039525 \\
\hline 2 & 0.0017 & - & - & - & 0.00371875 & - & 0.00371875 \\
\hline 3 & 0.00286875 & - & - & - & 0.00425 & - & 0.0030175 \\
\hline 4 & 0.0017 & - & - & - & 0.0053125 & - & 0.00371875 \\
\hline 5 & 0.00286875 & - & - & - & 0.00765 & - & 0.00393125 \\
\hline 6 & 0.0017 & - & - & - & 0.00425 & - & 0.0039525 \\
\hline 7 & 0.0017 & - & - & - & 0.0068 & - & 0.00393125 \\
\hline 8 & 0.00286875 & - & - & - & 0.00425 & - & 0.00371875 \\
\hline \multicolumn{8}{|l|}{ Ground water from the community } \\
\hline 1 & 0.0006375 & - & - & - & 0.00425 & - & - \\
\hline 2 & 0.00286875 & - & - & - & 0.0068 & - & - \\
\hline 3 & 0.010625 & & & & 0.0068 & & \\
\hline 4 & & & & & 0.00425 & & \\
\hline 5 & & & & & 0.0053125 & & \\
\hline 6 & & & & & 0.0068 & & \\
\hline 7 & & & & & 0.00765 & & \\
\hline 8 & & & & & 0.0031875 & & \\
\hline Mean & 0.0017448 & 0.001726 & 0.00022525 & 0.00338268733 & 0.0043279 & - & 0.00374265625 \\
\hline TDI (mg/kg/day) & 0.03 & 0.02 & 0.001 & 0.3 & 0.04 & 0.14 & - \\
\hline PTDI (mg/kg/day) & 0.06 & - & 0.06 & 60 & 3 & 9 & - \\
\hline
\end{tabular}

TDI: by USEPA; PTDI: by WHO/FAO.

3.2. Soil Samples of the Community. The highest concentration of copper was observed, and chromium concentration was the least one. Mean concentrations were in order of $\mathrm{Cu}(1.8928)>\mathrm{Co}(1.698)>\mathrm{Mn}(1.6228)>\mathrm{Cr}(0.9375)$.

3.3. Soil Samples of the Cement Industry. Copper was at the highest level of contamination: $\mathrm{Cu}(2.095)>\mathrm{Co}(1.849)>\mathrm{Cr}$ (0.8785).
3.4. Cement Industry Groundwater. It was enriched with copper with an average concentration of $2.4437 \mathrm{ppm}$ and the trend of heavy metals was $\mathrm{Cu}(2.4437)>\mathrm{Co}(1.93875)>\mathrm{Cr}$ (0.9437).

3.5. The Groundwater of Community. The trend of heavy metals observed in the groundwater of the community was $\mathrm{Cu}$ (2.65) > Cr (2.216). 


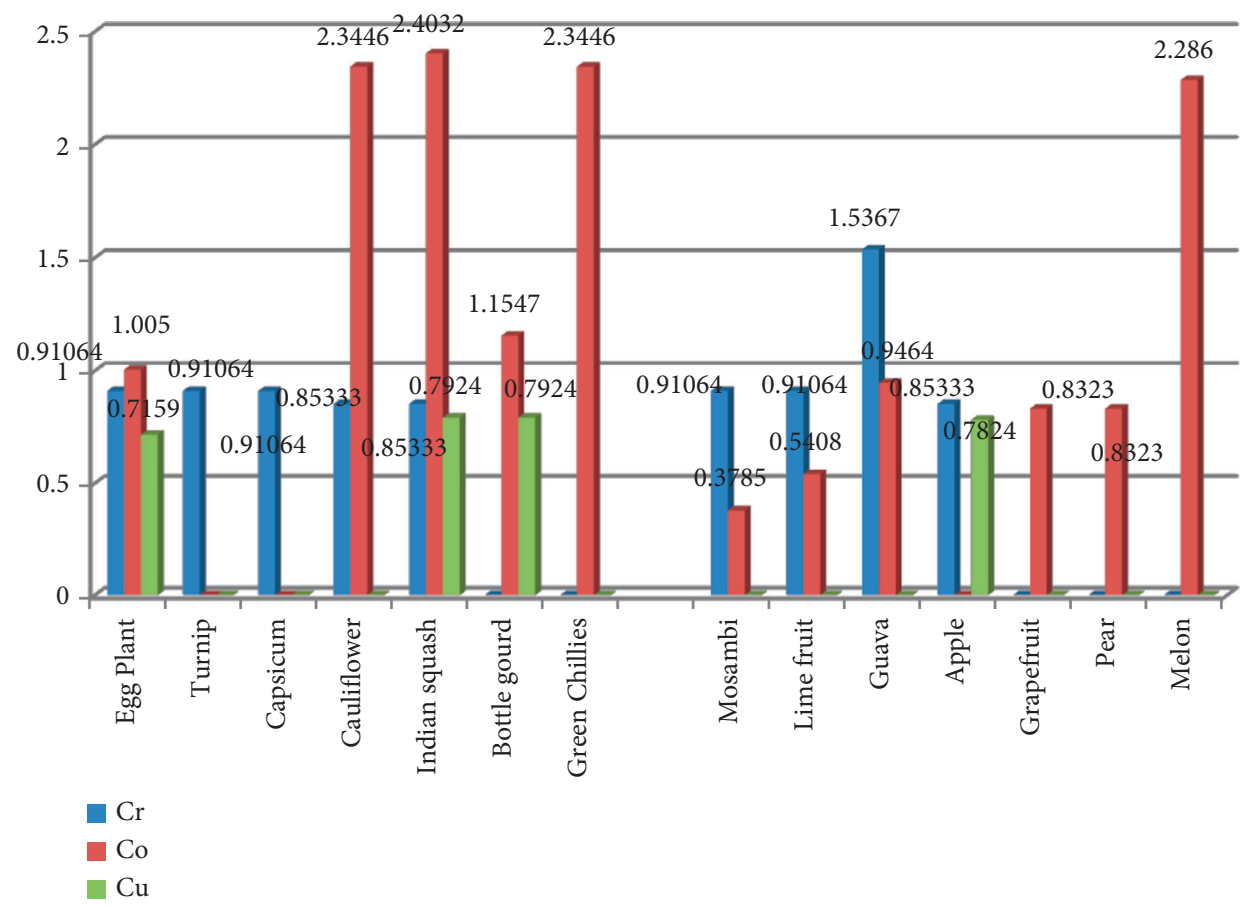

FIgURE 3: Bioaccumulation factor of heavy metal.

According to USEPA, there is a tolerable daily intake (TDI) of metals as follows: 0.03 for $\mathrm{Cr}$ and 0.02 for Ni. DIM daily intake of metals was calculated for fruits, vegetables, and groundwater samples, and the mean average of each metal was compared with provisional tolerable daily intake (PTDI) of WHO/FAO and TDI by USEPA as given in Table 3. The daily intake values for all metals were within the prescribed limits.

3.6. Target Hazard Quotient (THQ). THQ was calculated for the contaminated fruits and vegetables to find out the risk to consumers. The value of THQ in case of cobalt is greater than 1 for eggplant, bottle gourd, green chilies, cauliflower, and Indian squash. In vegetable samples, the highest risk was posed to the population by the consumption of Indian squash. The THQ for fruits contaminated with cobalt also poses serious health risks to the study area population. The trend of THQ in the case of cobalt was melon $>$ guava $>$ pear $>$ grapefruit $>$ lime fruit $>$ mosambi and for vegetables, Indian squash $>$ cauliflower $>$ green chilies $>$ bottle gourd $>$ eggplant. The concentration of heavy metals differs in the part of fruits and vegetables.

Nickel was detected in only one fruit with a concentration of $0.6 \mathrm{ppm}$ in apple. The calculated THQ value was 1 , which showed that the consumption of nickel-contaminated apples could cause health risks to people. THQ for eggplants with high levels of cadmium concentration was also not safe for the consuming population.

Zinc and chromium were present in vegetables and fruits, but their concentrations were within the standards, and the THQ results of fruits and vegetables contaminated with zinc and cadmium showed that their consumption was on the safe side as the values were $<1$.
THQ values in the case of chromium were all $>1$, which clearly means that they pose a risk on the population, and in fruit samples, guava poses the highest risks as its THQ was greater than the other Cr contaminated fruits. However, vegetables contaminated with chromium, eggplant, turnip, capsicum, cauliflower, and Indian squash pose a major threat to consumers' life more than fruits.

3.7. The Bioaccumulation Factor. The bioaccumulation factor was calculated by dividing the metal concentration in plants by the concentration of metal in soil shown in Figure 3.

BAF is used to estimate the capacity of plants for the accumulation of metals from contaminated soil. The calculated results of BAF showed that the transfer of metals from soil to plant was in the order of $\mathrm{Co}>\mathrm{Cr}>\mathrm{Cu}$. The least value of BAF was calculated in mosambi for cobalt. The metal with a higher value of BAF is more available for fruits and vegetables and more mobile in soil. Therefore, cobalt and chromium were absorbed more than the others. Calculated values of BAF in this study showed that the vegetation grown within the cement industry and nearby areas has the potential to accumulate cobalt and chromium. These heavy metals enter the food chain through the consumption of fruits and vegetables by humans and animals as they are nonbiodegradable and persist in the environment for a long time [28-30].

HRI was calculated to determine the risk on population by consuming fruits, vegetables, and water contaminated with heavy metals. The calculated value of HRI for cobalt was greater than 1 in all of the vegetables, groundwater samples, and fruits (i.e., for melon, HRI > 1). 
3.8. HRI Value for Cobalt. The values of HRI of all groundwater samples of the cement industry were $>1$, ranging from 3.9 to 3.1. So, the workers of the cement industry were at high risk. The index value for $\mathrm{Ni}, \mathrm{Cd}, \mathrm{Zn}$, and $\mathrm{Cu}$ was $<1$, meaning the workers and local inhabitants were safe. In case of $\mathrm{Cr}$ in fruits and vegetables, HRI was $<1$, but in groundwater samples of cement industry except for sample 1 , the values of all were greater than 1 , whereas, in case of groundwater from nearby area, samples 2 and 3 showed that the local inhabitants experience health risks. Sample 2 of the cement industry's groundwater poses health risks to industrial staff and workers. So, overall, the groundwater of the cement industry poses more health risks to the industrial staff and workers than other local inhabitants because of $>1$ values of the calculated HRI:

$$
\begin{aligned}
\text { Indian squash } & >\text { cauliflower }>\text { green chilies } \\
& >\text { bottle gourd }>\text { eggplant }>\text { melon } .
\end{aligned}
$$

\section{Conclusion}

It is concluded that cement production generates various pollutants of which heavy metals are the major ones. These toxic heavy metals are responsible for polluting the soil, groundwater reservoirs, fruits, and vegetables. Within the vicinity of the cement industry and its nearby area, soil and groundwater resources were highly contaminated by copper, whereas fruits and vegetables were enriched with $\mathrm{Zn}, \mathrm{Ni}, \mathrm{Co}$, $\mathrm{Cu}$, and $\mathrm{Cr}$. Toxic heavy metals like $\mathrm{Co}, \mathrm{Cu}$, and $\mathrm{Cr}$ have the highest potential to transfer from soil to plants and bioaccumulates. Risk indexes such as HRI and THQ was also calculated and it was seen that $\mathrm{Cu}, \mathrm{Co}, \mathrm{Ni}, \mathrm{Cd}$, and $\mathrm{Cr}$ pose serious health hazards.

\section{Data Availability}

The data used to support the findings of this study are included within the article.

\section{Conflicts of Interest}

The authors declare no conflicts of interest.

\section{References}

[1] O. H. G. Van and A. C. Padovani, "Cement manufacture and the environment part II: environmental challenges and opportunities," Journal of Industrial Ecology, vol. 7, no. 1, pp. 93-126, 2003.

[2] N. Ali, M. Anwer, A. Jaffar, and M. Raza, "The cement industry of Pakistan: a swot analysis," Journal for Studies in Management and Planning, vol. 1, pp. 236-245, 2015.

[3] M. S. Imbabi, C. Carrigan, and S. McKenna, "Trends and developments in green cement and concrete technology," International Journal of Sustainable Built Environment, vol. 1, no. 2, pp. 194-216, 2012.

[4] F. N. Stafford, M. D. Viquez, J. Labrincha, and D. Hotza, "Advances and challenges for the co-processing in Latin American cement industry," Procedia Materials Science, vol. 9, pp. 571-577, 2015.
[5] S. Mishra and N. A. Siddiqui, "A review on environmental and health impacts of cement manufacturing emissions," International Journal of Geology, Agriculture and Environmental Science, vol. 2, no. 3, pp. 26-31, 2014.

[6] H. Pekey Pekey. and M. Bakoglu, "Source apportionment of trace metals in surface waters of a polluted stream using multivariate statistical analyses," Marine Pollution Bulletin, vol. 49, no. 9-10, pp. 809-818, 2004.

[7] Y. Ouyang, J. Higman, J. Thompson, T. O'Toole, and D. Campbell, "Characterization and spatial distribution of heavy metals in sediment from Cedar and Ortega rivers subbasin," Journal of Contaminant Hydrology, vol. 54, no. 1-2, pp. 19-35, 2002.

[8] Y. Sang, Q. Li, C. Gu, and J. Chen, "Heavy metal-contaminated groundwater treatment by a novel nano fiber membrane," Desalination, vol. 223, pp. 349-360, 2008.

[9] C. Knight, G. C. Lalor, H. Robotham, and J. V. Witter, "Heavy metals in surface water and 521 stream sediments in Jamaica," Environmental Geochemistry and Health, vol. 19, no. 2, pp. 63-66, 1997.

[10] Y. Loubières, M. Bernier, A. Vieillard-Baron, B. Page, F. Jardin, and P. F. Jardin, "Acute, fatal, oral chromic acid poisoning," Journal of Toxicology: Clinical Toxicology, vol. 37, no. 3, pp. 333-336, 1999.

[11] WHO, Guidelines for Drinking-Water Quality, World Health Organization, Geneva, Switzerland, 2011, http://apps.who.int/ iris/bitstream/10665/44584/1/9789241548151_eng.pdf, 4th edition.

[12] G. M. A. Bermudez, M. Moreno, R. Invernizzi, R. Plá, and M. L. Pignata, "Heavy metal pollution in topsoils near a cement plant: the role of organic matter and distance to the source to predict total and $\mathrm{HCl}$-extracted heavy metal concentrations," Chemosphere, vol. 78, no. 4, pp. 375-381, 2010.

[13] N. Khan, G. Yaqub, and M. Tariq, "Assessment of health risk due to pesticide residues in fruits, vegetables, soil, and water," Journal of Chemistry, vol. 2020, Article ID 5497952, 7 pages, 2020.

[14] G. Yaqub, F. Ilyas, M. Idrees, and V. Mariyam, "Monitoring and risk assessment due to presence of heavy metals and pesticides in tea samples," Food Science and Technology, vol. 38, no. 4, pp. 625-628, 2018.

[15] A. I. Khalid and A. Sohail, "Monitoring and risk assessment due to presence of metals and pesticides residues in honey samples from the major honey producing forest belts and different brands," Food Science and Technology (Campinas), vol. 40, no. 1, pp. 331-335, 2020.

[16] C. Princewill and N. Adanma, "Metal concentration in soil and plants in abandoned cement factory," International Conference on Biotechnology and Environment Management IPCBEE, Singapore, vol. 18, pp. 146-150, 2011.

[17] O. A. Al-Khashman and R. A. Shawabkeh, "Metals distribution in soils around the cement factory in southern Jordan," Environmental Pollution, vol. 140, no. 3, pp. 387-394, 2006.

[18] B. T. Marfo, "Heavy metals contaminations of soil and water at Agbogbloshie scrap market, Accra," Ph. D thesis, 2014.

[19] T. B. Reddy, C. V. Ramana, C. Bhaskar, and P. J. Chandrababu, "Assessment of heavy metal study on ground water in and around Kapuluppada MSW site, Visakhapatnam, AP," International Journal of Science and Nature, vol. 3, pp. 468-471, 2012.

[20] R. A. Wuana and F. E. Okieimen, "Heavy metals in contaminated soils: a review of sources, chemistry, risks and best available strategies for remediation," International Scholarly Research Notices, vol. 2011, Article ID 402647, 20 pages, 2011. 
[21] H. Yongming, D. Peixuan, C. Junji, and E. S. Posmentier, "Multivariate analysis of heavy metal contamination in urban dusts of Xi'an, Central China," The Science of the Total Environment, vol. 355, no. 1-3, pp. 176-186, 2006.

[22] S. Khan, R. Farooq, S. Shahbaz, M. A. Khan, and M. Sadique, "Health risk assessment of heavy metals for population via consumption of vegetables," World Applied Sciences Journal, vol. 6, no. 12, pp. 1602-1606, 2009.

[23] A. Maleki, H. Amini, S. Nazmara, S. Zandi, and A. H. Mahvi, "Spatial distribution of heavy metals in soil, water, and vegetables of farms in Sanandaj, Kurdistan, Iran," Journal of Environmental Health Science and Engineering, vol. 12, no. 1, p. 136, 2014.

[24] M. H. H. Ali and K. M. Al-Qahtani, "Assessment of some heavy metals in vegetables, cereals and fruits in Saudi Arabian markets," The Egyptian Journal of Aquatic Research, vol. 38, no. 1 , pp. 31-37, 2012.

[25] G. Chauhan, "Toxicity study of metals contamination on vegetables grown in the vicinity of cement factory," International Journal of Scientific and Research Publication, vol. 4, no. 11, pp. 1-8, 2014.

[26] M. Jaishankar, T. Tseten, N. Anbalagan, B. B. Mathew, and K. N. Beeregowda, "Toxicity, mechanism and health effects of some heavy metals," Interdisciplinary Toxicology, vol. 7, no. 2, pp. 60-72, 2014.

[27] S. Martin and W. Griswold, "Human health effects of heavy metals," Environmental Science and Technology Briefs for Citizens, vol. 15, pp. 1-6, 2009.

[28] N. Bagdatlioglu, C. Nergiz, and P. G. Ergonul, "Heavy metal levels in leafy vegetables and some selected fruits," Journal für Verbraucherschutz und Lebensmittelsicherheit, vol. 5, no. 3-4, pp. 421-428, 2010.

[29] A. F. Abimbola, O. O. Kehinde-Phillips, and A. S. Olatunji, "The Sagamu cement factory, SW Nigeria: is the dust generated a potential health hazard?" Environmental Geochemistry and Health, vol. 29, no. 2, pp. 163-167, 2007.

[30] N. Ferré-Huguet, R. Martí-Cid, M. Schuhmacher, and J. L. Domingo, "Risk assessment of metals from consuming vegetables, fruits and rice grown on soils irrigated with waters of the Ebro River in Catalonia, Spain," Biological Trace Element Research, vol. 123, no. 1-3, pp. 66-79, 2008. 